\title{
Valorization and Storage Stability Assessment of Underutilized Fruit Carambola (Averrhoa carambola) in Bangladesh
}

\author{
K. Monalisa, M. Z. Islam*, S. M. Asif-Ul-Alam, M. M. Hoque \\ Department of Food Engineering and Tea Technology, Shahjalal University of Science \& Technology, Sylhet-3114, Bangladesh \\ *Corresponding author: zohurulislam.engg@gmail.com
}

Received March 12, 2014; Revised April 28, 2014; Accepted August 13, 2014

\begin{abstract}
An effort was made to develop value added products from underutilized fruit Carambola (Averrhoa carambola) to assess its prospect in marketability and evaluated the storage stability of quality attributes at $25-34^{\circ} \mathrm{C}$, $10^{\circ} \mathrm{C}$ and $0^{\circ} \mathrm{C}$ storage temperatures for 6 months. Carambola Jam showed $70.43 \pm 0.02 \%$ Carbohydrate, $1.14 \pm 0.04 \%$ Fiber, $0.47 \pm 0.01 \%$ Ash, $2.45 \mathrm{p}^{\mathrm{H}}, 68.40 \pm 0.02 \%$ TSS, $0.015 \mathrm{mg} / 100 \mathrm{~g}$ Vitamin-C, energy $284.87 \pm 0.2 \mathrm{Kcal}$ and in Squash $42.04 \pm 0.01 \%$ Carbohydrate, $0.08 \pm 0.01 \%$ Fiber, $0.39 \pm 0.04 \%$ Ash, $2.40 \pm 0.14 \mathrm{p}^{\mathrm{H}}, 40.70 \pm 0.03 \%$ TSS, $0.012 \pm 0.01 \mathrm{mg} / 100 \mathrm{~g}$ Vitamin-C, 170.04 $\pm 0.08 \mathrm{Kcal}$ energy. Storage studies showed Carambola Jam and Squash can store almost without any change for 3 months. With increasing the time in 6 months of storage TSS and acidity increases, on the other hand moisture content, $\mathrm{p}^{\mathrm{H}}$ and vitamin- $\mathrm{C}$ decreases. Vitamin-C retention is higher at $25-34^{\circ} \mathrm{C}$.
\end{abstract}

Keywords: Carambola, composition, Jam, Squash, storage study

Cite This Article: K. Monalisa, M. Z. Islam, S.M.Asif-Ul-Alam, and M. M. Hoque, "Valorization and Storage Stability Assessment of Underutilized fruit Carambola (Averrhoa carambola) in Bangladesh." American Journal of Food Science and Technology, vol. 2, no. 4 (2014): 134-138. doi: 10.12691/ajfst-2-4-5.

\section{Introduction}

The Carambola (Averrhoa carambola) is an attractive fruit of family Oxalidaceae, also known as Golden Star. The word Carambola is derived from the Sanskrit word karmaranga meaning "food appetizer". It is a good source of potassium, copper, as well as folate and pantothenic acid. The Ascorbic acid level of the star fruit is believed to be responsible for its sweet or sour taste. For a sweet fruit, the ascorbic acid level is around $10.40 \mathrm{mg}$ per $100 \mathrm{ml}$ of juice [1]. It is often consumed fresh and also processed into jam, jelly, sweets, fresh juice and cordial concentrate. Star fruit is rich in nutritive value - $100 \mathrm{~g}$ of Star fruit pulp contain 0.38 g Protein, 9.38 g Carbohydrates, 35.7 Calories, 0.08 g Fat, 89-91 g Moisture, 0.80-0.90 g Fiber, 0.26-0.40g Ash, 26-53.1mg Ascorbic Acid, 4.4-6 mg Calcium, 0.32-1.65 mg Iron, 15.5-21 mg Phosphorus, 0.003-0.552 mg Carotene, 0.03-0.038 mg Thiamine, 0.019-0.03 mg Riboflavin and 0.294-0.38 mg Niacin [2]. Carambola is mainly used in food preparation and has good medicinal properties. It is required that fruits have to be preserved fresh and make available throughout the year to fulfill the human dietary requirements. As the fruits being living entities, their metabolic activities continue even after harvest with a sum total effect on their degrading quality and composition. Processed Carambola products are not available in our market and very little work has been done on the processing of Carambola in our country. Bangladesh cannot use high technology, sophisticated machineries and equipment, skilled manpower and large capital investment in modern food processing industries as in developed countries. Therefore, it is important to develop and use low level appropriate technology for processing and preservation of processed Carambola products. So the scope of utilizing Carambola remains bright in Bangladesh. Development of varieties of products like jam and squash utilizing local produces is critically important for expanding the country's developing food industries. The present research work was carried out to search the appropriate technology to (1) develop Carambola Jam and Squash; and (2) Assess the quality retention of the products at $25-34^{\circ} \mathrm{C}, 10^{\circ} \mathrm{C}$ and $0^{\circ} \mathrm{C}$ storage temperatures.

\section{Materials and Methods}

The experiment was conducted in the department of Food Engineering and Tea Technology, Shahjalal University of Science and Technology, Sylhet, Bangladesh, 2013.

\subsection{Materials}

The fresh Carambola (Averrhoa carambola)was collected from the local market of Sylhet, Bangladesh.

\subsubsection{Extraction of Carambola fruit Juice}

The fully ripe, healthy and fresh fruit was washed thoroughly with potable water. The seeds were removed 
and then the fruit was blended by a blending machine. The juice thus obtained was preserved by freezing at $-20^{\circ} \mathrm{C}$.

\subsubsection{Processing of Jam}

Selections of fresh mature fruit were weighted and washed them thoroughly with cold water. Cut the washed fruits with a stainless steel knife into small pieces. Pulp was extracted from fruit and adjusted the $\mathrm{pH}$ by addition of citric acid or sodium hydroxide. Then the pulp was filtered, strained and mixed. Keep the mixed contract in deep container. Carefully decant the extract. Mixed the $450 \mathrm{~g}$ fruit pulp, $550 \mathrm{~g}$ sugar, $5 \mathrm{~g}$ citric acid was used to make $1 \mathrm{~kg}$ fruit jam. In addition $5 \mathrm{~g}$ of pectin (High Methoxy pectin: $\mathrm{DE}>50$ ) were added in the formulations. Pectin was mixed with equal amount of sugar in a stainless steel pot. The remaining sugar was mixed with fruit pulp and heated until the TSS become nearer to $55^{\circ}$ Brix. Then sugar mixed pectin was added and continued the heating until TSS becomes nearer to $58^{\circ}$ Brix. The citric acid was added and continued the heating. When TSS of the jelly becomes $68^{\circ}$ Brix, then the KMS was added and then poured in a sterilized glass bottle and parafinning the cap.

Table 1. Formulations of fruit Jam (1000 g)

\begin{tabular}{|c|c|}
\hline Ingredients & Amounts \\
\hline Pulp (g) & 450 \\
\hline Sugar (g) & 550 \\
\hline Citric Acid (g) & 5 \\
\hline Pectin (g) & 5 \\
\hline KMS (ppm) & 300 \\
\hline
\end{tabular}

\subsubsection{Processing of Squash}

Sugar, citric acid, juice and KMS were weighted as required separately. Water also measured according to calculation. Then, sugar and acid mixed in water (a small quantity of water to be taken out from the measured quantity to dissolve KMS later on). After that, heated the mixture to boil and strained through filter. Then, cool the syrup. The above syrup was mixed with the juice. Then KMS was dissolved in aforesaid quantity of water and added to the squash. Finally, poured into pasteurized bottles and sealed.

Table 2. Formulation of Carambola fruit Squash

\begin{tabular}{|c|c|}
\hline Ingredients & Amounts \\
\hline Juice $(\mathrm{ml})$ & 250 \\
\hline Sugar (g) & 372 \\
\hline Citric acid (g) & 11.50 \\
\hline KMS (g) & 0.52 \\
\hline Water (ml) & 365.54 \\
\hline
\end{tabular}

\subsection{Chemical Analysis}

Proximate composition like moisture, protein, fat, $\mathrm{p}^{\mathrm{H}}$, total soluble solid (TSS), fiber and ascorbic acid content of processed Carambola Jam and Squash analyzed with the following standard methods as described by Ranganna 1991 [3] and AOAC 2004 [4].

\subsection{Storage Study}

The storage stability and shelf life of products were carried out based on different analytical tests, such as moisture, $\mathrm{p}^{\mathrm{H}}$, acidity, total soluble solids and vitamin-C at three different storage temperature i.e. $0^{\circ} \mathrm{C}, 10^{\circ} \mathrm{C}$ and 25 $34^{\circ} \mathrm{C}$.

\section{Results and Discussion}

The results of various experiments conducted during the study period are summarized below.

\subsection{Products from Carambola}

Carambola has an impressive list of essential nutrients, antioxidants, and vitamins required for well-being. In this analysis Carambola used in a number of innovative ways to make Jams and Squash. The physicochemical composition of these products is presented in Table 3. Moisture content $28.5 \pm 0.01 \%$ and $57.20 \pm 0.02 \%$ in Jam and Squash respectively. Moisture and dry matter levels of any food material is a measure of the longevity or life span of the food. It indicates how long a food material can be stored without becoming moldy [5]. Carbohydrate of fruit is less concentrated because of their high water content. Fruits rich in carbohydrate provide a high amount of energy. Table 8 shows the amount of energy $284.87 \pm 0.2 \mathrm{Kcal}$ in Jam and $170.04 \pm 0.08 \mathrm{Kcal}$ in squash. Protein and fat content of both products is very low. Ash content gives an indication of minerals present in a particular food sample and it is very important in many biochemical reactions which aid the physiological functioning of major metabolic processes in the body. Ash contents $0.47 \pm 0.01 \%$ in Jam and $0.47 \pm 0.01 \%$ in Squash.

Table 3. Chemical composition of Products from Carambola fruit

\begin{tabular}{|c|c|c|}
\hline Parameters & Carambola Jam & Carambola Squash \\
\hline Moisture (\%) & $28.5 \pm 0.01$ & $57.20 \pm 0.02$ \\
\hline Carbohydrate (\%) & $70.43 \pm 0.02$ & $42.04 \pm 0.01$ \\
\hline Protein (\%) & $0.45 \pm 0.01$ & $0.29 \pm 0.01$ \\
\hline Fat (\%) & $0.15 \pm 0.03$ & $0.08 \pm 0.02$ \\
\hline Ash (\%) & $0.47 \pm 0.01$ & $0.47 \pm 0.01$ \\
\hline Fiber (\%) & $1.14 \pm 0.04$ & $0.08 \pm 0.01$ \\
\hline PH & $2.45 \pm 0.1$ & $2.40 \pm 0.10$ \\
\hline Acidity (\%) & $0.51 \pm 0.01$ & $0.58 \pm 0.01$ \\
\hline Total Soluble Solid (\%) & $68.4 \pm 0.02$ & $40.7 \pm 0.03$ \\
\hline Vitamin- C (mg\100g) & $0.015 \pm 0.001$ & $0.012 \pm 0.01$ \\
\hline Energy (Kcal) & $284.87 \pm 0.2$ & $170.04 \pm 0.08$ \\
\hline
\end{tabular}

Triplicate analyses were performed and the results were expressed in $\mathrm{g} \%$ as mean values \pm standard deviation

The recommended daily dietary fiber intake is $28 \mathrm{~g} /$ day for adult women and $36 \mathrm{~g} /$ day for adult men [6]. Most health advisory groups provide guidance for obtaining the recommended levels of fiber consumption from foods, especially fruits, vegetables, and whole grains [6]. In this study, it was found that dietary fiber, the important constituent of fruit pulp based products $1.14 \pm 0.04 \%$ and $0.08 \pm 0.01 \%$ in Crambola Jam and Squash respectively. The $\mathrm{p}^{\mathrm{H}}$ contents in Jam 2.45 \pm 0.1 and $2.40 \pm 0.1$ in Squash. This value is little bit lower than fresh star fruit juice 4.39 \pm 0.01 [15]. Generally the higher TSS indicates more sugar in the pulp. The more ripe the fruits the more amount of sugar in fruits [7]. According to Norman and Potter 1976, the sugar content of fresh fruit ranges between $2 \%$ and $30 \%$.The study showed $68.4 \pm 0.02 \%$ and $40.7 \pm 0.03 \%$ TSS in Carambola Jam and Squash. The increased rate may be due to addition of sugar during processing. In this study it was observed that vitamin $\mathrm{C}$ (ascorbic acid), $0.015 \pm 0.001 \mathrm{mg}$ and $0.012 \pm 0.01 \mathrm{mg}$ per $100 \mathrm{~g}$ in Jam and Squash respectively. In a rigorous 
review of over 200 research articles on the health benefits of vitamin $\mathrm{C}$, concluded that the totality of evidence from the available human studies strongly suggests that a dietary intake of about $100 \mathrm{mg} /$ day of vitamin $\mathrm{C}$ is associated with a reduced incidence of and mortality from heart disease, stroke, and cancer [8].

Table 4. Storage Stability of Carambola Jam

\begin{tabular}{|c|c|c|c|c|c|}
\hline & \\
\hline $\begin{array}{c}\text { Day } \\
\text { Temperature }\end{array}$ & & TSS (\%) & $\mathrm{P}^{\mathrm{H}}$ & Acidity (\%) & Vitamin-C (mg\100g) \\
\hline \multicolumn{6}{|c|}{ 0 Days } \\
\hline $25-34^{\circ} \mathrm{C}$ & $31.98 \pm 0.02$ & $68.00 \pm 0.01$ & $3.5 \pm 0.01$ & $0.47 \pm 0.001$ & $0.0056 \pm 0.001$ \\
\hline $10^{\circ} \mathrm{C}$ & $31.98 \pm 0.01$ & $68.02 \pm 0.01$ & $3.5 \pm 0.01$ & $0.47 \pm 0.001$ & $0.0056 \pm 0.001$ \\
\hline $0^{\circ} \mathrm{C}$ & $31.98 \pm 0.01$ & $68.02 \pm 0.01$ & $3.5 \pm 0.01$ & $0.47 \pm 0.001$ & $0.0056 \pm 0.001$ \\
\hline \multicolumn{6}{|c|}{15 Days } \\
\hline $25-34^{\circ} \mathrm{C}$ & $31.98 \pm 0.02$ & $68.00 \pm 0.01$ & $3.5 \pm 0.01$ & $0.47 \pm 0.001$ & $0.0056 \pm 0.001$ \\
\hline $10^{\circ} \mathrm{C}$ & $31.98 \pm 0.01$ & $68.02 \pm 0.01$ & $3.5 \pm 0.01$ & $0.47 \pm 0.001$ & $0.0056 \pm 0.001$ \\
\hline $0^{\circ} \mathrm{C}$ & $31.98 \pm 0.01$ & $68.02 \pm 0.01$ & $3.5 \pm 0.01$ & $0.47 \pm 0.001$ & $0.0056 \pm 0.001$ \\
\hline \multicolumn{6}{|c|}{30 Days } \\
\hline $25-34^{\circ} \mathrm{C}$ & $31.98 \pm 0.02$ & $68.00 \pm 0.01$ & $3.5 \pm 0.01$ & $0.47 \pm 0.001$ & $0.0056 \pm 0.001$ \\
\hline $10^{\circ} \mathrm{C}$ & $31.98 \pm 0.01$ & $68.02 \pm 0.01$ & $3.5 \pm 0.01$ & $0.47 \pm 0.001$ & $0.0056 \pm 0.001$ \\
\hline $0^{\circ} \mathrm{C}$ & $31.98 \pm 0.01$ & $68.02 \pm 0.01$ & $3.5 \pm 0.01$ & $0.47 \pm 0.001$ & $0.0056 \pm 0.001$ \\
\hline \multicolumn{6}{|c|}{45 Days } \\
\hline $25-34^{\circ} \mathrm{C}$ & $31.97 \pm 0.02$ & $68.00 \pm 0.01$ & $3.4 \pm 0.01$ & $0.48 \pm 0.001$ & $0.0056 \pm 0.001$ \\
\hline $10^{\circ} \mathrm{C}$ & $31.98 \pm 0.01$ & $68.02 \pm 0.01$ & $3.5 \pm 0.01$ & $0.47 \pm 0.001$ & $0.0056 \pm 0.001$ \\
\hline $0^{\circ} \mathrm{C}$ & $31.98 \pm 0.01$ & $68.02 \pm 0.01$ & $3.5 \pm 0.01$ & $0.47 \pm 0.001$ & $0.0056 \pm 0.001$ \\
\hline \multicolumn{6}{|c|}{60 Days } \\
\hline $25-34^{\circ} \mathrm{C}$ & $31.97 \pm 0.02$ & $68.00 \pm 0.01$ & $3.3 \pm 0.01$ & $0.47 \pm 0.001$ & $0.0056 \pm 0.001$ \\
\hline $10^{\circ} \mathrm{C}$ & $31.98 \pm 0.01$ & $68.02 \pm 0.01$ & $3.4 \pm 0.01$ & $0.47 \pm 0.001$ & $0.0056 \pm 0.001$ \\
\hline $0^{\circ} \mathrm{C}$ & $31.98 \pm 0.01$ & $68.02 \pm 0.01$ & $3.4 \pm 0.01$ & $0.47 \pm 0.001$ & $0.0056 \pm 0.001$ \\
\hline \multicolumn{6}{|c|}{75 Days } \\
\hline $25-34^{\circ} \mathrm{C}$ & $31.96 \pm 0.02$ & $68.02 \pm 0.01$ & $3.3 \pm 0.01$ & $0.47 \pm 0.001$ & $0.0056 \pm 0.001$ \\
\hline $10^{\circ} \mathrm{C}$ & $31.97 \pm 0.01$ & $68.03 \pm 0.01$ & $3.4 \pm 0.01$ & $0.47 \pm 0.001$ & $0.0056 \pm 0.001$ \\
\hline $0^{\circ} \mathrm{C}$ & $31.97 \pm 0.01$ & $68.03 \pm 0.01$ & $3.4 \pm 0.01$ & $0.47 \pm 0.001$ & $0.0056 \pm 0.001$ \\
\hline \multicolumn{6}{|c|}{90 Days } \\
\hline $25-34^{\circ} \mathrm{C}$ & $31.95 \pm 0.02$ & $68.02 \pm 0.01$ & $3.2 \pm 0.01$ & $0.48 \pm 0.001$ & $0.0056 \pm 0.001$ \\
\hline $10^{\circ} \mathrm{C}$ & $31.96 \pm 0.01$ & $68.04 \pm 0.01$ & $3.3 \pm 0.01$ & $0.47 \pm 0.001$ & $0.0056 \pm 0.001$ \\
\hline $0^{\circ} \mathrm{C}$ & $31.96 \pm 0.01$ & $68.03 \pm 0.01$ & $3.3 \pm 0.01$ & $0.47 \pm 0.001$ & $0.0056 \pm 0.001$ \\
\hline \multicolumn{6}{|c|}{105 Days } \\
\hline $25-34^{\circ} \mathrm{C}$ & $31.94 \pm 0.02$ & $68.03 \pm 0.01$ & $3.1 \pm 0.01$ & $0.49 \pm 0.001$ & $0.0056 \pm 0.001$ \\
\hline $10^{\circ} \mathrm{C}$ & $31.96 \pm 0.01$ & $68.04 \pm 0.01$ & $3.3 \pm 0.01$ & $0.47 \pm 0.001$ & $0.0055 \pm 0.001$ \\
\hline $0^{\circ} \mathrm{C}$ & $31.95 \pm 0.01$ & $68.04 \pm 0.01$ & $3.3 \pm 0.01$ & $0.47 \pm 0.001$ & $0.0054 \pm 0.001$ \\
\hline \multicolumn{6}{|c|}{120 Days } \\
\hline $25-34^{\circ} \mathrm{C}$ & $31.90 \pm 0.02$ & $68.04 \pm 0.01$ & $3.0 \pm 0.01$ & $0.49 \pm 0.001$ & $0.0056 \pm 0.001$ \\
\hline $10^{\circ} \mathrm{C}$ & $31.94 \pm 0.01$ & $68.05 \pm 0.01$ & $3.3 \pm 0.01$ & $0.47 \pm 0.001$ & $0.0054 \pm 0.001$ \\
\hline $0^{\circ} \mathrm{C}$ & $31.95 \pm 0.01$ & $68.04 \pm 0.01$ & $3.3 \pm 0.01$ & $0.47 \pm 0.001$ & $0.0053 \pm 0.001$ \\
\hline \multicolumn{6}{|c|}{135 Days } \\
\hline $25-34^{\circ} \mathrm{C}$ & $31.88 \pm 0.02$ & $68.05 \pm 0.01$ & $3.0 \pm 0.01$ & $0.50 \pm 0.001$ & $0.0056 \pm 0.001$ \\
\hline $10^{\circ} \mathrm{C}$ & $31.92 \pm 0.01$ & $68.06 \pm 0.01$ & $3.2 \pm 0.01$ & $0.47 \pm 0.001$ & $0.0054 \pm 0.001$ \\
\hline $0^{\circ} \mathrm{C}$ & $31.91 \pm 0.01$ & $68.05 \pm 0.01$ & $3.3 \pm 0.01$ & $0.47 \pm 0.001$ & $0.0052 \pm 0.001$ \\
\hline \multicolumn{6}{|c|}{150 Days } \\
\hline $25-34^{\circ} \mathrm{C}$ & $31.86 \pm 0.02$ & $68.07 \pm 0.01$ & $2.99 \pm 0.01$ & $0.52 \pm 0.001$ & $0.0055 \pm 0.001$ \\
\hline $10^{\circ} \mathrm{C}$ & $31.90 \pm 0.01$ & $68.06 \pm 0.01$ & $3.2 \pm 0.01$ & $0.48 \pm 0.001$ & $0.0054 \pm 0.001$ \\
\hline $0^{\circ} \mathrm{C}$ & $31.91 \pm 0.01$ & $68.05 \pm 0.01$ & $3.3 \pm 0.01$ & $0.48 \pm 0.001$ & $0.0051 \pm 0.001$ \\
\hline \multicolumn{6}{|c|}{165 Days } \\
\hline $25-34^{\circ} \mathrm{C}$ & $31.85 \pm 0.02$ & $68.10 \pm 0.01$ & $2.98 \pm 0.01$ & $0.55 \pm 0.001$ & $0.0055 \pm 0.001$ \\
\hline $10^{\circ} \mathrm{C}$ & $31.89 \pm 0.01$ & $68.06 \pm 0.01$ & $3.1 \pm 0.01$ & $0.49 \pm 0.001$ & $0.0054 \pm 0.001$ \\
\hline $0^{\circ} \mathrm{C}$ & $31.89 \pm 0.01$ & $68.05 \pm 0.01$ & $3.3 \pm 0.01$ & $0.49 \pm 0.001$ & $0.0051 \pm 0.001$ \\
\hline \multicolumn{6}{|c|}{180 Days } \\
\hline $25-34^{\circ} \mathrm{C}$ & $31.80 \pm 0.02$ & $68.12 \pm 0.01$ & $2.97 \pm 0.01$ & $0.58 \pm 0.001$ & $0.0053 \pm 0.001$ \\
\hline $10^{\circ} \mathrm{C}$ & $31.85 \pm 0.01$ & $68.08 \pm 0.01$ & $3.1 \pm 0.01$ & $0.52 \pm 0.001$ & $0.0049 \pm 0.001$ \\
\hline $0^{\circ} \mathrm{C}$ & $31.87 \pm 0.01$ & $68.06 \pm 0.01$ & $3.3 \pm 0.01$ & $0.50 \pm 0.001$ & $0.0045 \pm 0.001$ \\
\hline
\end{tabular}

Triplicate analyses were performed and the results were expressed in $\mathrm{g} \%$ as mean values \pm standard deviation

\subsection{Studies of Storage Stability}

\subsubsection{Storage Stability of Carambola Jam and Squash}

During storage the changes in moisture, TSS, $\mathrm{P}^{\mathrm{H}}$, acidity and vitamin-C was observed on a fifteen days interval at $25-34^{\circ} \mathrm{C}, 10^{\circ} \mathrm{C}$ and $0^{\circ} \mathrm{C}$ for Carambola Jam (Table 4) and Squash (Table 5). Table 5, shows all quality parameters remain almost unchanged from 0 days to 3 months long storage. Observation from fourth to sixth month shows moisture content gradually decreases but
TSS increases. These results are in agreement with the results of Rehman et al., who reported that total soluble solids increased from 66.5 to 68.8 in strawberry jam after 60 days. The increase in total soluble solids contents of the product may be due to the solubilization of jam constituents during storage [9]. Vitamin $\mathrm{C}$ content at $0^{\circ} \mathrm{C}$ was more reduced than that of other two temperatures. Other authors reported decreases of vitamin $C$ during the storage of fruit products [10]. The ascorbic acid content decreased due to oxidation of ascorbic acid to dehydroascorbic acid [11] and the values of proteins 
decreased also during storage. The results are in complete agreement with other researchers [12]. The increase in acidity and decrease in $\mathrm{p}^{\mathrm{H}}$ may be ascribed to rise in the concentration of weakly ionized acid and their salts during storage [13]. This increase in acidity and decrease in $\mathrm{pH}$ might also be due to ascorbic acid degradation, hydrolysis of pectin or degradation of polysaccharides and oxidation of reducing sugar [10]. In case of water loss shows the same pattern that was studied by Zainon Mohd. Ali [14]. All parameters of the products under tentative storage time and temperature support that these products could be stored for 6 months long.

Table 5. Storage Stability of Carambola Squash

\begin{tabular}{|c|c|c|c|c|c|}
\hline Day & \multirow{2}{*}{ Moisture (\%) } & \multirow{2}{*}{ TSS (\%) } & \multirow{2}{*}{$\mathrm{P}^{\mathrm{H}}$} & \multirow{2}{*}{ Acidity (\%) } & \multirow{2}{*}{ Vitamin-C (mg\100 g) } \\
\hline Temperature & & & & & \\
\hline \multicolumn{6}{|c|}{0 Days } \\
\hline $25-34^{\circ} \mathrm{C}$ & $57.20 \pm 0.02$ & $40.7 \pm 0.03$ & $2.40 \pm 0.14$ & $0.58 \pm 0.01$ & $0.012 \pm 0.01$ \\
\hline $10^{\circ} \mathrm{C}$ & $57.20 \pm 0.02$ & $40.7 \pm 0.03$ & $2.40 \pm 0.14$ & $0.58 \pm 0.01$ & $0.012 \pm 0.01$ \\
\hline $0^{\circ} \mathrm{C}$ & $57.20 \pm 0.02$ & $40.7 \pm 0.03$ & $2.40 \pm 0.14$ & $0.58 \pm 0.01$ & $0.012 \pm 0.01$ \\
\hline \multicolumn{6}{|c|}{15 Days } \\
\hline $25-34^{\circ} \mathrm{C}$ & $57.20 \pm 0.02$ & $40.7 \pm 0.03$ & $2.40 \pm 0.14$ & $0.58 \pm 0.01$ & $0.012 \pm 0.01$ \\
\hline $10^{\circ} \mathrm{C}$ & $57.20 \pm 0.02$ & $40.7 \pm 0.03$ & $2.40 \pm 0.14$ & $0.58 \pm 0.01$ & $0.012 \pm 0.01$ \\
\hline $0^{\circ} \mathrm{C}$ & $57.20 \pm 0.02$ & $40.7 \pm 0.03$ & $2.40 \pm 0.14$ & $0.58 \pm 0.01$ & $0.012 \pm 0.01$ \\
\hline \multicolumn{6}{|c|}{30 Days } \\
\hline $25-34^{\circ} \mathrm{C}$ & $57.20 \pm 0.02$ & $40.7 \pm 0.03$ & $2.40 \pm 0.14$ & $0.58 \pm 0.01$ & $0.012 \pm 0.01$ \\
\hline $10^{\circ} \mathrm{C}$ & $57.20 \pm 0.02$ & $40.7 \pm 0.03$ & $2.40 \pm 0.14$ & $0.58 \pm 0.01$ & $0.012 \pm 0.01$ \\
\hline $0^{\circ} \mathrm{C}$ & $57.20 \pm 0.02$ & $40.7 \pm 0.03$ & $2.40 \pm 0.14$ & $0.58 \pm 0.01$ & $0.012 \pm 0.01$ \\
\hline \multicolumn{6}{|c|}{45 Days } \\
\hline $25-34^{\circ} \mathrm{C}$ & $57.20 \pm 0.02$ & $40.7 \pm 0.03$ & $2.40 \pm 0.14$ & $0.59 \pm 0.01$ & $0.012 \pm 0.01$ \\
\hline $10^{\circ} \mathrm{C}$ & $57.20 \pm 0.01$ & $40.7 \pm 0.03$ & $2.40 \pm 0.14$ & $0.58 \pm 0.01$ & $0.012 \pm 0.01$ \\
\hline $0^{\circ} \mathrm{C}$ & $57.20 \pm 0.02$ & $40.7 \pm 0.03$ & $2.40 \pm 0.14$ & $0.58 \pm 0.01$ & $0.012 \pm 0.01$ \\
\hline \multicolumn{6}{|c|}{60 Days } \\
\hline $25-34^{\circ} \mathrm{C}$ & $57.18 \pm 0.02$ & $47.5 \pm 0.03$ & $2.40 \pm 0.14$ & $0.60 \pm 0.01$ & $0.012 \pm 0.01$ \\
\hline $10^{\circ} \mathrm{C}$ & $57.19 \pm 0.02$ & $40.6 \pm 0.03$ & $2.40 \pm 0.14$ & $0.59 \pm 0.01$ & $0.011 \pm 0.01$ \\
\hline $0^{\circ} \mathrm{C}$ & $57.19 \pm 0.01$ & $40.6 \pm 0.03$ & $2.40 \pm 0.14$ & $0.59 \pm 0.01$ & $0.011 \pm 0.01$ \\
\hline \multicolumn{6}{|c|}{75 Days } \\
\hline $25-34^{\circ} \mathrm{C}$ & $57.18 \pm 0.02$ & $40.7 \pm 0.03$ & $2.39 \pm 0.14$ & $0.62 \pm 0.01$ & $0.012 \pm 0.01$ \\
\hline $10^{\circ} \mathrm{C}$ & $57.18 \pm 0.02$ & $40.9 \pm 0.03$ & $2.40 \pm 0.14$ & $0.60 \pm 0.01$ & $0.011 \pm 0.01$ \\
\hline $0^{\circ} \mathrm{C}$ & $57.18 \pm 0.01$ & $40.9 \pm 0.03$ & $2.39 \pm 0.14$ & $0.60 \pm 0.01$ & $0.011 \pm 0.01$ \\
\hline \multicolumn{6}{|c|}{90 Days } \\
\hline $25-34^{\circ} \mathrm{C}$ & $57.18 \pm 0.02$ & $40.7 \pm 0.03$ & $2.39 \pm 0.14$ & $0.64 \pm 0.01$ & $0.012 \pm 0.01$ \\
\hline $10^{\circ} \mathrm{C}$ & $57.18 \pm 0.02$ & $40.9 \pm 0.03$ & $2.40 \pm 0.14$ & $0.61 \pm 0.01$ & $0.011 \pm 0.01$ \\
\hline $0^{\circ} \mathrm{C}$ & $57.18 \pm 0.01$ & $40.9 \pm 0.03$ & $2.39 \pm 0.14$ & $0.61 \pm 0.01$ & $0.011 \pm 0.01$ \\
\hline \multicolumn{6}{|c|}{105 Days } \\
\hline $25-34^{\circ} \mathrm{C}$ & $57.15 \pm 0.03$ & $40.8 \pm 0.03$ & $2.33 \pm 0.12$ & $0.64 \pm 0.01$ & $0.012 \pm 0.01$ \\
\hline $10^{\circ} \mathrm{C}$ & $57.16 \pm 0.01$ & $41.0 \pm 0.01$ & $2.39 \pm 0.10$ & $0.61 \pm 0.01$ & $0.012 \pm 0.01$ \\
\hline $0^{\circ} \mathrm{C}$ & $57.17 \pm 0.02$ & $41.0 \pm 0.01$ & $2.39 \pm 0.10$ & $0.61 \pm 0.01$ & $0.010 \pm 0.01$ \\
\hline \multicolumn{6}{|c|}{120 Days } \\
\hline $25-34^{\circ} \mathrm{C}$ & $57.13 \pm 0.03$ & $40.9 \pm 0.03$ & $2.30 \pm 0.12$ & $0.65 \pm 0.01$ & $0.012 \pm 0.01$ \\
\hline $10^{\circ} \mathrm{C}$ & $57.14 \pm 0.01$ & $41.0 \pm 0.01$ & $2.38 \pm 0.10$ & $0.61 \pm 0.01$ & $0.012 \pm 0.01$ \\
\hline $0^{\circ} \mathrm{C}$ & $57.12 \pm 0.02$ & $41.1 \pm 0.01$ & $2.37 \pm 0.10$ & $0.61 \pm 0.01$ & $0.010 \pm 0.01$ \\
\hline \multicolumn{6}{|c|}{135 Days } \\
\hline $25-34^{\circ} \mathrm{C}$ & $57.10 \pm 0.03$ & $40.9 \pm 0.03$ & $2.26 \pm 0.12$ & $0.67 \pm 0.01$ & $0.012 \pm 0.01$ \\
\hline $10^{\circ} \mathrm{C}$ & $57.11 \pm 0.01$ & $41.1 \pm 0.01$ & $2.35 \pm 0.10$ & $0.62 \pm 0.01$ & $0.012 \pm 0.01$ \\
\hline $0^{\circ} \mathrm{C}$ & $57.12 \pm 0.02$ & $41.2 \pm 0.01$ & $2.34 \pm 0.10$ & $0.62 \pm 0.01$ & $0.010 \pm 0.01$ \\
\hline \multicolumn{6}{|c|}{150 Days } \\
\hline $25-34^{\circ} \mathrm{C}$ & $25-34^{\circ} \mathrm{C}$ & $25-34^{\circ} \mathrm{C}$ & $25-34^{\circ} \mathrm{C}$ & $25-34^{\circ} \mathrm{C}$ & $25-34^{\circ} \mathrm{C}$ \\
\hline $10^{\circ} \mathrm{C}$ & $10^{\circ} \mathrm{C}$ & $10^{\circ} \mathrm{C}$ & $10^{\circ} \mathrm{C}$ & $10^{\circ} \mathrm{C}$ & $10^{\circ} \mathrm{C}$ \\
\hline $0^{\circ} \mathrm{C}$ & $0^{\circ} \mathrm{C}$ & $0^{\circ} \mathrm{C}$ & $0^{\circ} \mathrm{C}$ & $0^{\circ} \mathrm{C}$ & $0^{\circ} \mathrm{C}$ \\
\hline \multicolumn{6}{|c|}{165 Days } \\
\hline $25-34^{\circ} \mathrm{C}$ & $25-34^{\circ} \mathrm{C}$ & $25-34^{\circ} \mathrm{C}$ & $25-34^{\circ} \mathrm{C}$ & $25-34^{\circ} \mathrm{C}$ & $25-34^{\circ} \mathrm{C}$ \\
\hline $10^{\circ} \mathrm{C}$ & $10^{\circ} \mathrm{C}$ & $10^{\circ} \mathrm{C}$ & $10^{\circ} \mathrm{C}$ & $10^{\circ} \mathrm{C}$ & $10^{\circ} \mathrm{C}$ \\
\hline $0^{\circ} \mathrm{C}$ & $0^{\circ} \mathrm{C}$ & $0^{\circ} \mathrm{C}$ & $0^{\circ} \mathrm{C}$ & $0^{\circ} \mathrm{C}$ & $0^{\circ} \mathrm{C}$ \\
\hline \multicolumn{6}{|c|}{180 Days } \\
\hline $25-34^{\circ} \mathrm{C}$ & $25-34^{\circ} \mathrm{C}$ & $25-34^{\circ} \mathrm{C}$ & $25-34^{\circ} \mathrm{C}$ & $25-34^{\circ} \mathrm{C}$ & $25-34^{\circ} \mathrm{C}$ \\
\hline $10^{\circ} \mathrm{C}$ & $10^{\circ} \mathrm{C}$ & $10^{\circ} \mathrm{C}$ & $10^{\circ} \mathrm{C}$ & $10^{\circ} \mathrm{C}$ & $10^{\circ} \mathrm{C}$ \\
\hline $0^{\circ} \mathrm{C}$ & $0^{\circ} \mathrm{C}$ & $0^{\circ} \mathrm{C}$ & $0^{\circ} \mathrm{C}$ & $0^{\circ} \mathrm{C}$ & $0^{\circ} \mathrm{C}$ \\
\hline
\end{tabular}

Triplicate analyses were performed and the results were expressed in $\mathrm{g} \%$ as mean values \pm standard deviation

\section{Conclusion}

The study indicates that a good quality value added product could be produced from Carambola. Consumers can take all the products without changing quality facts starting 0 day to 3 months from any storage temperature and the products can be store for 6 months. Therefore, the present study is a sign of bright prospect of processing of indigenous fruit products in Bangladesh. Up scaling and validation are needed for the developed technologies before recommendation and transfer to the entrepreneurs for commercial production and marketing. Increase consumption of processed products will prevent the 
incidence of malnutrition disorders and generate more income to the farmers and traders.

\section{Acknowledgements}

The authors gratefully acknowledge to the University Research Centre for financial support and Department of Food Engineering and Tea Technology, Shahjalal University of Science and Technology, Sylhet, Bangladesh for providing the facilities to carry out this research.

\section{Statement of Competing Interests}

The authors have no competing interests.

\section{References}

[1] Chang, C.T., Y. C. Chen, J.T. Fang and C.C. Huang 2002. Star fruit (Averrhoacarambola) intoxication: an important cause of consciousness disturbance in patients with failure. Pubmed 24 (3): 379-82.

[2] USDA (US Department of Agriculture) 2005. US Department of Health and Human Services. Dietary Guidelines for Americans. Washington, DC: USDA.

[3] Ranganna, S. 1991. Handbook of Analysis and quality control for fruit and vegetable products, McGraw Hill Book Company, $2^{\text {nd }}$ edition.

[4] AOAC 2004. Official method of Analysis, 11th Edition, Association of Official Agricultural Chemists, Washington DC.
[5] Fellows, P.J. 2000. Food Processing Technology, Principles and Practice. $2^{\text {nd }}$ edn. Wood Head Publishing Ltd. England, pp 234280.

[6] USDA (US Department of Agriculture) 2005. US Department of Health and Human Services. Dietary Guidelines for Americans. Washington, DC: USDA.

[7] Haque, M.N., B.K. Saha, M.R. Karim, and M.N.H. Bhuiyan 2009. Evalution of Nutritional and Physico Chemical Properties of Several Selected Fruits in Bangladesh. Bangladesh J. Sci. Ind. Res. 44 (3): 353-358.

[8] online: http://lpi.oregonstate.edu/s-s00/recommend.html [accessed may. 2000].

[9] Muhammad, A., Y. Durrani, A. Zeb, M. Ayub and J. Ullah 2008. Developments of diet jam from apple grown in swat (NWFP). Sarhad J. Agric., Vol. 24, No. 3.

[10] Hussain, I. and Shakir I. 2010. Chemical and organoleptic characteristics of jam prepared from indigenous varities of apricot and apple. World Journal of Dairy \& Food Sciences 5 (1): 73-78.

[11] Vidhya, R. and A. Narain A. 2011. Formulation and evaluation of preserved products utilizing under exploited fruit, wood apple (Limoniaacidissima). American-Eurasian J. Agric. \& Environ. Sci. 10 (1): $112-118$.

[12] Souad, A.M., P. Jamal and K.S. Olorunnisola 2012. Effective jam preparations from watermelon waste. IFRJ 19 (4): 1545-1549.

[13] Bajwa, E. E., Z.N. Parwaz, A. Javed and N.Ahmad 2003. Development, standardization and storage studies on grape fruit apple marmalade. Pak. J. Food Sci. 13 (3): 11-15.

[14] ZainonMohd. Ali, Lieng-Hong Chin, MuthusamyMarimuthu, Hamid Lazan. 2014. Low temperature storage and modified atmosphere packaging of carambola fruit and their effects on ripening related texture changes, wall modification and chilling injury symptoms.Posharvest Biology and Technology, 33:181-192.

[15] Rajeev Bhat, Suhaida Binti Ameran, Han Ching Voon, A.A. Karim, Liong Min Tze. 2011. Quality attributes of starfruit (Averrhoacarambola L.) juice treated with ultraviolet radiation. Food Chemistry 127 (2011) 641-644. 